\title{
Correspondence
}

\section{Gulf casualties}

DeAR SiRS

It seems increasingly likely that a major land battle will soon be fought in the Middle East. The NHS has been asked to prepare to treat significant numbers of physically injured casualties. Mental health services will need to offer support and advice to these patients and their relatives if the experience of recent conflicts in Northern Ireland (Curran et al, 1990) and the Falklands War (Jones \& Lovett, 1987) are anything to go by. Not unreasonably, the Army has deployed the majority of its uniformed psychiatric personnel to the war zone where they will principally treat acute stress reactions (battleshock) according to the principles of forward psychiatry (Richardson, 1978).

It seems to us that there may possibly be a relative lack of expertise left in the UK to advise on specific military aspects of such problems as post-traumatic stress disorder. Here in Northallerton we have a fairly unique situation where $50 \%$ of our consultant staff have had recent experience with the Royal Army Medical Corps. If we can offer advice to our colleagues anywhere within the UK on this subject, we would be delighted to do so and we can be contacted on Northallerton (0609) 779911 extension 3927/ 4202.

Department of Mental Health

G. E. P. VINCENTI J. D. MUMFORD

Rutson Hospital

Northallerton

North Yorkshire DL7 8EN

\section{References}

Curran, P. S. et al (1990) Psychological consequences of the Enniskillen bombing. British Journal of Psychiatry, 156, 479-482.

JONES, G. H. \& LOVETT, J. W. T. (1987) Delayed psychiatric sequelae among Falklands war veterans. Journal of the Royal College of General Practitioners, 37, 34-35.

RichaRDSON, F. M. (1978) Fighting Spirit: psychological factors in war. London: Lee Cooper.

\section{Medical audit in a lithium clinic}

DeAr Sirs

We chose to audit 18 years' experience in a lithium clinic to examine the quality and cost effectiveness of the service. The case notes of 150 patients in the West Norfolk and Wisbech Health Authority taking lithium for one or more years were examined. Except for
19 cases, all records were complete. We compared our results with a prospective study from a lithium clinic by Vestergaard \& Schou (1988). Unipolar was defined as in their paper but bipolar disorder, grades 1, 2 and 3 according to Akiskal (1985). Where data were lacking, comparisons were made with other publications.

The average patient age was 54 years, $65 \%$ were female and $35 \%$ male. Their patients had an average age of 42.6 years but $80 \%$ were female. On lithium, $66 \%$ of our patients were diagnosed as bipolar, $29 \%$ unipolar and $5 \%$ miscellaneous, compared to their figures of $38 \%, 27 \%$ and $35 \%$ respectively.

Our patients had one episode of illness every 2.1 years before but every 4.6 years on lithium treatment. This translated into 0.74 episodes before and 0.21 episodes during lithium treatment per year, which was a highly significant reduction $(P<0.001)$. Their patients had one episode of illness every 2.3 years before lithium but further data are unavailable.

The mean serum level over the 18 years and for 1989 was $0.63 \mathrm{mmol} / \mathrm{l}$. The mean daily dose was $789 \mathrm{mg}$, approximately equivalent to $20.6 \mathrm{mmol}$ of lithium. Eighty-eight per cent took Priadel, 7\% Camcolit, and 5\% Litarex. Seventy-six per cent of patients took lithium at night only, $13 \%$ twice daily, $6 \%$ in the morning, $4 \%$ three times, and $1 \%$ four times daily. Their mean daily dose was $23.2 \mathrm{mmol}$ and mean serum level $0.68 \mathrm{mmol} / \mathrm{l}$. Most of their patients took Litarex, twice daily.

The mean frequency of lithium, thyroid and renal function monitoring was once every 1.5, 6.6 and 7 months respectively, and for the year 1989, once every $1.7,4.6$ and 4.8 months respectively. In 1989 , 1,075 lithium, 390 thyroid function and 370 creatinine tests were done on our patients at a total cost of $£ 2,067.50$ or $£ 13.75$ per patient. No comparable figures are available in their paper. Our figures, except for 1989, compare well with recommendations for lithium sampling of once every 1-3 months and renal/thyroid testing every 6-12 months (NIMH/NIH, 1985).

Eleven per cent developed hypothyroidism needing replacement therapy, and one patient became thyrotoxic. They give no data on thyroid disorders but our figures compare well with a published prevalence of lithium-induced hypothyroidism of 5-30\% (Jefferson et al, 1987).

A tremor was developed by $3 \% ; 15 \%$ of their patients developed a tremor initially which dropped after five years to $3-5 \%$. Weight gain was a complaint of $2.6 \%$ but lithium was the sole treatment in 
only two. They found a $10-20 \mathrm{~kg}$ weight gain in $21 \%$ and $2 \%$ of their patients respectively, and though difficult to compare directly, the percentages of excessive weight gain and complaints of the same are almost identical in both studies.

Gastro-intestinal disturbances including nausea and vomiting, loose motions and a salty taste in the mouth was reported by $3 \% ; 6 \%$ of their patients had diarrhoea.

Seven per cent had raised serum creatinine levels ( $>125 \mu \mathrm{mol} / \mathrm{l}$ ) but $28 \%$ had at least one raised level at some time previously; $3 \%$ had persistently raised levels (3 or more consecutive levels) with mean values ranging from 137 to 184 . Only one of these had a creatinine clearance and this was normal. Of their patients, $0.7 \%$ had a raised serum creatinine ( $>130 \mu \mathrm{mol} / \mathrm{l})$ but none of these showed any significant reduction of creatinine clearance on lithium.

There were no symptomatic cases of lithium toxicity compared to two cases of toxicity in their study. We had three suicides of clinic patients, not involving lithium and they had the same number.

In conclusion, our audit has shown that monitoring frequency for thyroid and renal function ought to be reduced, creatinine clearances obtained for persistently raised levels, the rationale for daily divided doses of lithium reviewed and patients weighed at each visit. Otherwise, the lithium clinic provides a cost effective service, with potential implications for general practitioner budget holders and other purchasers of psychiatric services.

Fulbourn Hospital

PATRICK O'Brien

\section{Cambridge CBI SEF}

\section{References}

Akiskal, H. A. (1985) A proposed clinical approach to chronic and "resistant" depression: evaluation and treatment. Journal of Clinical psychiatry, 46, 32-36.

Jefferson, J. W., Greist, J. H., Ackerman, D. L. \& CARROLL, J. A. (1987) Lithium Encyclopaedia for Clinical Practice. Second edition. Wahington DC: American Psychiatric Press.

National Institute of Mental Health/National InstiTUTE OF HEALTH CONSENSUS DEVELOPMENT CONFERENCE STATEMENT (1985) Mood disorders: pharmacological prevention of recurrences. American Journal of Psychiatry, $142,469-476$.

Vestergand, P. \& Schou, M. (1988) Prospective studies on a lithium cohort. Acta Psychiatrica Scandinavica, 78, 421-426.

\section{Clinical audit}

DeAr SIRS

I read with interest the letter from A. K. Shah (Psychiatric Bulletin, December 1990, 14, 748). The form of clinical audit which he comments upon had been practised for some time in our Department of Psychiatry. For the past 18 months we have held fortnightly audit meetings, and in alternate meetings a consultant has reviewed the case notes of a patient randomly selected from another consultant's team. The review of the notes follows a standardised format and covers three areas. The first area is the structure of the records and looks at whether the appropriate paperwork is present and filed correctly. The second area looks at the content of the notes and sees whether an adequate history is taken, mental state recorded, physical examination made, investigations performed and progress notes recorded regularly. Also a discharge plan is looked at and the timing and adequacy of the discharge summary is noted. The third area is management appraisal where the objective is to see how well the case in managed.

A recent South-West region audit meeting showed that this form of case note review has been widely adopted by psychiatric departments in the SouthWest. Despite some problems at first, generally the experience has been a positive one. In Exeter, the main disadvantage at first was that the juniors felt somewhat paranoid as they were initially excluded from the audit meetings and it was mainly their work which was being scrutinised. This was readily addressed by the inclusion of all grades of medical staff in the audit meetings. The gains from this process have been marked. Firstly, we are now much more aware of our colleagues' working practices. Secondly, we are now more critically aware of our own standards of work and ways of improving these. Finally, it seems that this has had a generalised effect on raising morale.

\section{Wonford House Hospital}

SARAH OKE

\section{Wonford, Exeter EX2 5AF}

\section{DeAR Sirs}

I read with interest Dr Shah's letter (Psychiatric Bulletin, December 1990, 14, 748) describing an intensive and confrontational form of clinical audit in the field of medicine for the elderly. Such methods are not new, and are certainly finding their way into psychiatric practice and education in Liverpool.

Five years ago, I was a senior house officer in geriatrics in North Wales, and attended fortnightly meetings in which consultants from another team would present a detailed audit of one or two sets of recent case notes in a similar way to that described by Dr Shah. This exercise was, indeed, frightening, not least to the junior medical staff, but had clear educational value, improving my own standards of notekeeping enormously.

These methods are now to be used on a regular basis in the case conference meetings normally presented by postgraduate psychiatry trainees in 